\title{
Optimization of cellulase production by bacillus sp. BPPT CC RK2 with pH and temperature variation using response surface methodology
}

\author{
Misri Gozan ${ }^{1, *}$, Andre Fahriz Harahap ${ }^{1}$, Chandra Paska Bakti ${ }^{1}$, and Siswa Setyahadi ${ }^{2}$ \\ ${ }^{1}$ Chemical Engineering Department, Faculty of Engineering, Universitas Indonesia, Kampus UI Depok, 16424, Indonesia \\ ${ }^{2}$ Center for Bioindustrial Technology, Agency for The Assessment and Application of Technology, MH Thamrin 8, Jakarta, 10340, \\ Indonesia
}

\begin{abstract}
Indonesia has abundant ethanol biomass feedstocks. However the second-generation ethanol production process is still hampered by the unavailability of cellulase enzyme in the process of decomposition of lignocellulose into saccharides that can be processed into ethanol through fermentation. Cellulase is known as exozyme produced by Bacillus sp. in submerged fermentation. In this study, cellulase production by Bacillus sp. CC BPPT RK2 on natural and abundant agricultural waste substrates (rice bran and coconut water) was evaluated by investigating the optimum conditions for cellulase production in a $50 \mathrm{ml}$ laboratory scale. Preliminary test using Luria Bentani (LB) medium with additional CMC (1\%) were done to select optimum range of $\mathrm{pH}$ and Temperature. The preliminary tests results were then followed by optimization of $\mathrm{pH}$ and temperature, which were carried out using response surface methodology (RSM). RSM optimization model showed optimum values 6.23 for $\mathrm{pH}$ and $40.04{ }^{\circ} \mathrm{C}$, with 14 terms (each with 1 degree of freedom), 4 linear effects, 6 interaction effects and 4 quadratic effects. These optimization by RSM results were slightly different compared to preliminary test, showing the effect of interactions between parameters. The characteristics of interaction among variables tested against the cellulase activity are reported in this study including: positive effects on cellulase activity of the resulting responses; negative interactions affecting the response of cellulase activity; synergistic interaction; and antagonistic interactions between each other.
\end{abstract}

\section{Introduction}

Second generation bioethanol is one of the alternative energy pathways that have less adverse effects to the environment [1]. The use of raw material resources of second generation bioethanol are not in conflict with the needs of food, as happened in the first-generation bioethanol. Second generation bioethanol feedstocks are organic wastes containing wood (lignocellulose) which are very abundant in nature $[2,3]$. By producing second generation bioethanol, the organic wastes are used to something that is economically valuable.

Although the raw materials of second generation bioethanol are readily available, organic wastes may not be directly used as the substrates of fermentation to produce ethanol, because these wastes (lignocellulosic) need to be converted first into monosaccharides (glucose). Then the resulting glucose can be fermented into ethanol. [2]

Various methods to destroy lignocellulose has been done, both physically and chemically. One of the most effective method is through the hydrolysis reaction. The most promising method to hydrolyse cellulose is to use enzymes, e.g. cellulases [2]. The current problem to produce the second-generation bioethanol in Indonesia is the unavailability of cellulase enzymes for lignocellulose degradation process. For that, one of the efforts that need to be done is to produce cellulase enzyme in the country. Producing cellulase enzyme on an industrial scale is very expensive $[2,4,5]$. The cost of cellulase production can reach $50 \%$ of the total cost of cellulose hydrolysis by cellulase. This is related with low specific activity of cellulase, which requires the use of large amounts of cellulase to satisfy the amount of hydrolysable cellulose [5]. Therefore, it is necessary to reduce the production cost. One way to optimize the production is to optimize the parameters of the operating conditions of production in order to get the maximum production of cellulase enzyme [6].

Bacillus sp. has known as one of the microorganisms that can produce the enzyme cellulase [4, 7-9]. Although the production of cellulase by this type of bacteria is not as much as the production of cellulase by fungi (i.e. Trichoderma reesei), cellulase production using bacteria brings several advantages, including (i) having higher growth rate than fungi (ii) less inhibited by material already hydrolysed, and (iii) easier genetic engineering $[2$, 8].

The aim of this study was to find the optimum production parameters ( $\mathrm{pH}$ and temperature) that produce cellulase in the maximum amount by using Bacillus $s p$. BPPT CC RK2 on rice bran and coconut water as

\footnotetext{
* Corresponding author: $\underline{\operatorname{mrgozan} @ \text { gmail.com }}$
} 
substrates. Rice bran and coconut water are among the abundant source of bioethanol feedstocks from agricultural waste [1]. The bacteria Bacillus sp. BPPT CC RK2 is a collection of bacteria belonging to BPPT while rice bran and coconut water substrates were chosen as substitutes for $\mathrm{C}$ and $\mathrm{N}$ sources due to abundant availability in nature.

The optimization process is done by using statistical analysis method namely Response Surface Methodology (RSM). The conventional way to perform optimization of enzyme production parameter is very expensive and takes a long time [5, 10-14]. The optimization using RSM method is also utilized in other field of engineering [15, 16]. Therefore, in the presence of RSM method using software (Design-Expert $\left.{ }^{\circledR}\right)$, it is expected that the optimization process can be much faster and accurate.

\section{Methods}

\subsection{Enzyme Production}

Luria Bertani (LB) solution was used as a standard medium for enzyme production with composition per litre are $10 \mathrm{~g}$ peptone, $5 \mathrm{~g}$ yeast extract and $5 \mathrm{~g} \mathrm{NaCl}$. This solution was added with $1 \%$ cellulose $[11,17]$. The medium was then dissolved by water and sterilized in an autoclave at $121^{\circ} \mathrm{C}$ and $1.2 \mathrm{~atm}$ for 15 minutes.

Bacillus sp. BPPT CC RK2 isolate was inoculated as much as 1-2 ose into LB agar medium then incubated at $37^{\circ} \mathrm{C}$ for 24 hours [11]. These inoculate would be used as experiment stock. Starter medium was made by inoculating 1-2 ose Bacillus sp. Isolate was then added into the sterilized LB medium which was $10 \%$ of total production volume then incubated at $37^{\circ} \mathrm{C}$ for 6 hours. Agitation was done at $150 \mathrm{rpm}$. The production of enzyme was done by inoculating the starter medium to the production medium, and then incubated at $37^{\circ} \mathrm{C}$ for 24 hours. Agitation was also done at $150 \mathrm{rpm}$.

After 24 hours, enzyme was collected by centrifuging the broth at $6000 \mathrm{rpm}$ using High Speed Refrigerated Centrifuge Himac CR21G and rotor R10A2 for 15 minutes at $4^{\circ} \mathrm{C}$. Supernatant was taken as crude enzyme fraction. This crude enzyme was then analysed to investigate protein content and enzyme activity.

\subsection{Temperature and pH Optimization}

For preliminary experiments of $\mathrm{pH}$ optimization, this method was similar to the production of enzymes, but with slight modification. The modification was done by varying the $\mathrm{pH}$ value as well as the temperature. $\mathrm{pH}$ was set to $6.0 ; 6.5 ; 7.0 ; 7.5$; and 8.0 while temperature was set to $25{ }^{\circ} \mathrm{C}$; $30{ }^{\circ} \mathrm{C} ; 35{ }^{\circ} \mathrm{C} ; 40{ }^{\circ} \mathrm{C} ; 45{ }^{\circ} \mathrm{C}$; and $50{ }^{\circ} \mathrm{C}$. Optimization was done here using one-variable-at-a-time method, so that in one experiment only one variable is varied.

\subsection{Optimization using Response Surface Methodology}

Centralized Composite Design was used to develop a mathematical model using Design-Expert ${ }^{\circledR}$ 7.1.5 software. The obtained equation would be used to calculate the optimum fermentation condition. The result was then be checked with ANOVA. The procedure was then to find the optimum conditions from the obtained equation [7, 10, 12-14].

\subsection{Analysis of Enzyme Activity}

The cellulase activity test performed in this experiment is a test of endo $\beta$-1, 4-glucanase (EC 3.2.1.4) or commonly referred to as CMCase. The CMCase test was chosen because it relates to the fact that the most dominant number of lignocellulose contained in cellulose is endo $\beta$ 1, 4-glucose [7, 4]. Although in this test only CMCases were analysed because these enzymes were the most dominant, it does not mean that others were not produced. It was reported that for insoluble crystalline cellulose such as those possessed by bran, cellulose such as exoglycanase and betaglucosidase species were also produced [2].

CMCase activity was measured by reacting the sample in $1 \mathrm{~mL}$ of $1 \% \mathrm{CMC}$ solution, $0,05 \mathrm{M}$ phosphate buffer ( $\mathrm{pH} 7.0)$ in which the enzyme sample volume was $100 \mathrm{ml}$, and the solvent volume was $900 \mathrm{ml}$ [18]. The reaction lasted for 30 minutes and was incubated at $50{ }^{\circ} \mathrm{C}$. Sugar derivatives resulting from the reaction was determined by the Miller method [19]. One unit (U) is defined as the amount of enzyme releasing $1 \mathrm{~mol}$ of reduced sugar from $\mathrm{CMC}$ every minute at $50{ }^{\circ} \mathrm{C}$. The concentration of byproducts of reduced sugar from the reaction is equivalent to 3-amino, 5-nitrosalicylic acid. This substance can be observed by spectroscopy due to high absorbance at 540 $\mathrm{nm}$ wavelength. The cellulase activity was calculated according to the equation

$$
\text { Activity }(\mathrm{U} / \mathrm{ml})=\frac{\mathrm{mg} \text { glucose } \times 1000}{\mathrm{Mr} \text { glucose } \times 30 \mathrm{~min} \times 0.1 \mathrm{ml}}
$$

\subsection{Protein Analysis}

Enzyme protein content was determined by Lowry phenol reagent method [20]. Alkaline conditions can be generated from the phosphate buffer or phosphate buffer saline (PBS). One liter of PBS solution consisted of $8 \mathrm{~g}$ $\mathrm{NaCl} ; 0.2 \mathrm{~g} \mathrm{KCl}: 1.44 \mathrm{~g} \mathrm{KH}_{2} \mathrm{PO}_{4}$ and $0.24 \mathrm{~g} \mathrm{Na}_{2} \mathrm{HPO}_{4}$. PBS solution was adjusted to $\mathrm{pH} 7.4$ by addition of $\mathrm{NaOH}$ or $\mathrm{HCl}$. Lowry reagent consisted of three kinds of solution (A, B and C). One liter of solution A consisted of $20 \mathrm{~g}$ $\mathrm{Na}_{2} \mathrm{CO}_{3}$ and $0.4 \mathrm{~g} \mathrm{NaOH}$, one liter of solution $\mathrm{B}$ consisted of $10 \mathrm{~g} \mathrm{CuSO}_{4}$, and one liter of solution $\mathrm{C}$ consisted of $2 \mathrm{~g}$ $\mathrm{NaKC}_{4} \mathrm{H}_{4} \mathrm{O}_{6}$.

Lowry reagent was made by mixing those solutions with ratio of volume of $\mathrm{A}: \mathrm{B}: \mathrm{C}$ is $98: 1: 1$. Protein standard solution was prepared from Bovine Serum Albumin (BSA) by varying the concentration 100$1000 \mu \mathrm{g} / \mathrm{mL}$, where $100 . \mathrm{ddH}_{2} \mathrm{O}$ interval was used as blank. At first as much as $20 \mu \mathrm{L}$ of each BSA solution was reacted with $180 \mu \mathrm{L}$ PBS solution to make alkaline 
conditions followed by addition of $2 \mathrm{ml}$ of fresh reagent. After stirring with vortex, the analyte was incubated for 10 minutes and then reacted with $200 \mu \mathrm{L}$ Follin Ciocalteu reagent and incubated for 30 minutes. As a result, solution containing the protein will change color from clear to blue. Quantitative analysis was performed using a visible spectrophotometer instrument with $750 \mathrm{~nm}$ wavelength.

\section{Results and Discussion}

\section{$3.1 \mathrm{pH}$ Preliminary Test}

Bacillus sp. can live in various $\mathrm{pH}$ conditions. However, the $\mathrm{pH}$ of the production operations has an impact, not only on how the bacteria metabolize but also on how the bacteria react to existing substrates. Bacillus sp. produces cellulase in the $\mathrm{pH}$ range $4-8[4,6]$. Because of that, variation of $\mathrm{pH}$ was performed for each fermentation from fairly acidic $\mathrm{pH}(\mathrm{pH} 6)$ up to fairly high $\mathrm{pH}(\mathrm{pH} 8)$. The adjusted $\mathrm{pH}$ was the $\mathrm{pH}$ of initial condition of the process. Figure 1 showed that Bacillus sp. produced cellulase with the highest activity at $\mathrm{pH} 7.5$. At low $\mathrm{pH}$, produced cellulase had low activity. The produced cellulase activity continued to increase as the operating $\mathrm{pH}$ increased until it dropped dramatically when the operating $\mathrm{pH}$ was 8 . Higher $\mathrm{pH}$ might have an effect to the ionization state of acidic or basic amino acids. The basic amino acids have amine functional groups in their side chains that can readily affected $[21,22]$.

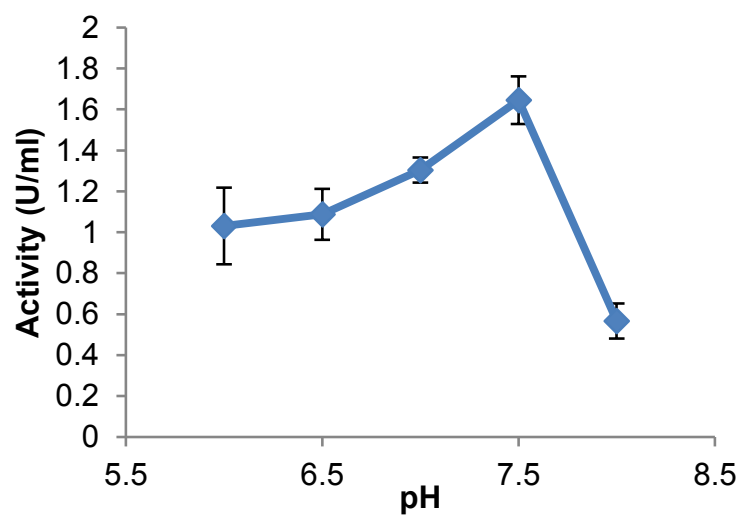

Fig. 1. Effect of $\mathrm{pH}$ on cellulase activity

The optimum $\mathrm{pH}$ condition on the preliminary test of $\mathrm{LB}+\mathrm{CMC}$ media by fermentation conditions at $37^{\circ} \mathrm{C}$ and $150 \mathrm{rpm}$ for 24 hours was 7.5. Similarly, other author [9] used the strain of Bacillus sp. derived from termites with fermentation conditions of $37{ }^{\circ} \mathrm{C}$ and $\mathrm{CMC}$ as substrate, with results not much different from thi study where the optimum $\mathrm{pH}$ was 7.2.

\subsection{Temperature Preliminary Test}

Likewise $\mathrm{pH}$, the temperature also has impact on bacterial metabolism. Temperature commonly used in the fermentation of bacteria in general is $37^{\circ} \mathrm{C}$. Temperature variation was performed from $25^{\circ} \mathrm{C}$ to $50^{\circ} \mathrm{C}$ with reference to the temperature where the origin of the bacteria Bacillus sp. CC BPPT RK2, where newspaper termite lives at room temperature $\left(\sim 30^{\circ} \mathrm{C}\right)$. From the data obtained (Fig. 2), the operating temperature resulting high activity cellulase production was not far from $37^{\circ} \mathrm{C}$, which was between $35^{\circ} \mathrm{C}$ and $40^{\circ} \mathrm{C}$. Temperature that produced cellulase production with the highest activity was $40^{\circ} \mathrm{C}$. At low temperature $\left(25^{\circ} \mathrm{C}\right)$, produced cellulase activity tends to be low, as well as at high temperature ( $50^{\circ} \mathrm{C}$ ), but activity remained lower at low temperature. This is related to the metabolism of the bacteria Bacillus $s p$., although at high temperature enzyme that plays role can be better, but if it exceeds the ability it will damage the enzyme and will reduce the rate of metabolism. Even in low temperature, although enzyme in the metabolism of Bacillus sp. is undamaged or denatured, enzyme retains a low activity because the heat received as an activation energy in transition is small.

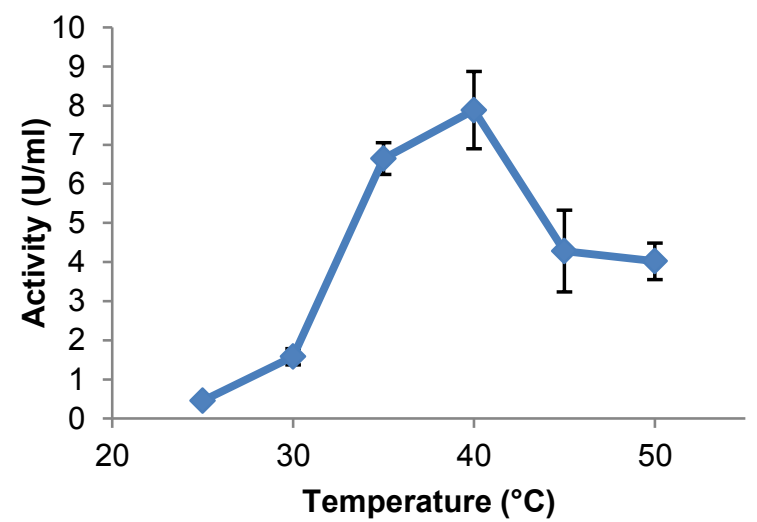

Fig. 2. Effect of temperature on cellulase activity

The optimum temperature value $\left(40{ }^{\circ} \mathrm{C}\right)$ on cellulase production optimization using Bacillus sp. on natural substrates was also reported [22] but the $\mathrm{pH}$ of the research condition differed slightly from this study. This research also showed that cellulase production reached optimum when Bacillus sp. BPPT CC RK2 was in exponential phase in which bacteria grows rapidly in that phase. Denaturation of enzyme resulted from higher temperature was reported by many authors [10, 21, 22].

\section{$3.3 \mathrm{pH}$ and Temperature Optimization Using RSM}

From the results of this research, the quadratic model was chosen as the surface model of the activity response to $\mathrm{pH}$, temperature and substrate (carbon and nitrogen source). The resulting model is in the form of a mathematical equation which when compiled: enzyme activity with $Y$, $\mathrm{C}$ with $X_{1}, \mathrm{~N}$ with $X_{2}, \mathrm{pH}$ with $X_{3}$ and temperature with $X_{4}$, is

$Y_{\mathrm{i}}=-18.51-2,08 X_{1}-1.52 X_{2}+11.17 X_{3}+2.12 X_{4}+$ 1.13.10-2 $X_{1} X_{2}-0.07 X_{1} X_{3}+1.93 .10^{-2} X_{1} X_{4}+0.12 X_{2} X_{3}-$ 3.91.10-2 $X_{2} X_{4}-0.01 X_{3} X_{4}+2.38 .10^{-2} X_{1}^{2}-3.38 .10^{-2} X_{2}^{2}$ $-0.79 X_{3}^{2}-0.05 X_{4}^{2}$ 
From Fig. 3 it is shown that the highest activity response of the given model is at a $\mathrm{pH}$ value of 6.23 and a temperature of $40.04^{\circ} \mathrm{C}$. From the $3 \mathrm{D}$ response graph (Fig. 4), it is shown that enzyme activity tends to decrease at high $\mathrm{pH}$. The optimum $\mathrm{pH}$ value is also in acidic condition. This proves that the optimum value of $\mathrm{pH}$ preliminary test using pure substrate $(\mathrm{CMC})$ can not be equated with the optimum value of RSM using natural substrate (rice bran) as its carbon source [4].

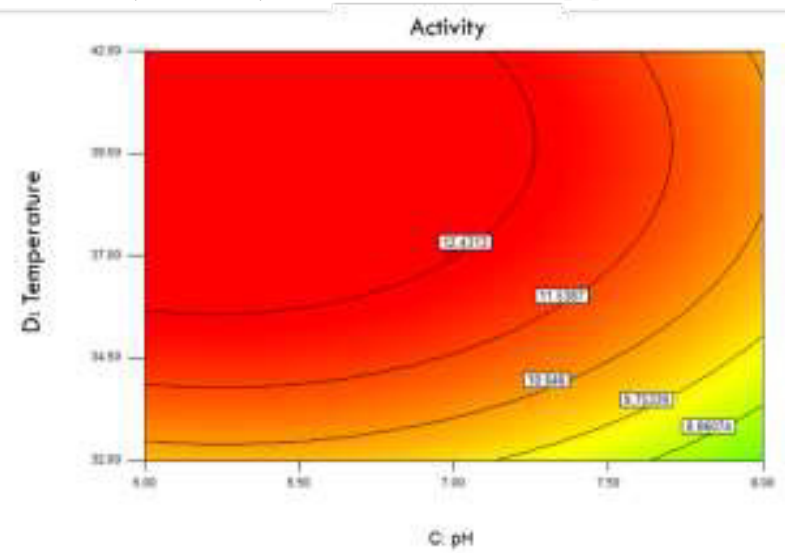

Fig. 3. Contour plot of cellulase activity on $\mathrm{pH}$ and temperature variations $(\mathrm{C}: 50 \%, \mathrm{~N}: 20 \%)$

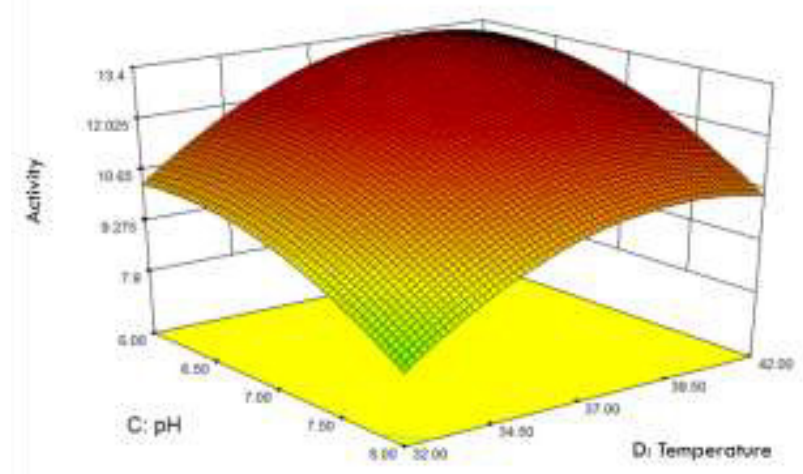

Fig. 4. 3D Graphic of cellulase activity on $\mathrm{pH}$ and temperature variations (C: $50 \%$, N: $20 \%)$

\subsection{Interaction Between Response Variables}

To know the interaction of responses between variables contained in the equations obtained, it is needed to refer to the result of the analysis of variance (ANOVA) model. The equation model obtained in this experiment has 14 terms with each term having 1 degree of freedom. The term consists of 4 linear effects, 6 interaction effects and 4 quadratic effects.

In Table 1, A denotes the concentration of carbon source, $\mathrm{B}$ denotes the concentration of nitrogen source, $\mathrm{C}$ denotes $\mathrm{pH}$ and $\mathrm{D}$ denotes temperature. The term consisting of a single letter (single variable) denotes a linear effect and a two-letter term (two variables), denotes the interaction effect.

The interaction between $\mathrm{pH}$ and temperature has no significant effect on the resulting cellulase activity. However, the interaction between $\mathrm{pH}$ and rice bran concentration, $\mathrm{pH}$ and nitrogen concentration, bran temperature and concentration, as well as the temperature and concentration of nitrogen, still have a significant effect on the response of the resulting cellulase activity. And to know what the effect of each term is, it is needed to look at the estimated coefficients of each term.

Table 1. ANOVA of cellulase activity RSM model

\begin{tabular}{|l|r|r|r|r|r|}
\hline Source & $\begin{array}{r}\text { Sum of } \\
\text { Squares }\end{array}$ & \multicolumn{1}{c|}{ df } & \multicolumn{1}{c|}{ Square } & \multicolumn{1}{c|}{$\begin{array}{c}\text { Value } \\
\text { Probalue }\end{array}$} \\
\hline Model & 181.82 & 14 & 12.99 & 91.62 & $<0.0001$ \\
\hline A-C & 51.77 & 1 & 51.77 & 365.22 & $<0.0001$ \\
\hline B-N & 7.85 & 1 & 7.85 & 55.39 & $<0.0001$ \\
\hline C-pH & 7.42 & 1 & 7.42 & 52.31 & $<0.0001$ \\
\hline D-suhu & 3.27 & 1 & 3.27 & 23.1 & 0.0002 \\
\hline AB & 1.28 & 1 & 1.28 & 9 & 0.009 \\
\hline AC & 1.79 & 1 & 1.79 & 12.65 & 0.0029 \\
\hline AD & 3.73 & 1 & 3.73 & 26.33 & 0.0001 \\
\hline BC & 6.07 & 1 & 6.07 & 42.81 & $<0.0001$ \\
\hline BD & 15.26 & 1 & 15.26 & 107.65 & $<0.0001$ \\
\hline CD & 0.058 & 1 & 0.058 & 0.41 & 0.5303 \\
\hline$A^{\wedge} 2$ & 9.68 & 1 & 9.68 & 68.31 & $<0.0001$ \\
\hline$B^{\wedge} 2$ & 19.53 & 1 & 19.53 & 137.76 & $<0.0001$ \\
\hline $\mathrm{C}^{\wedge} 2$ & 17.13 & 1 & 17.13 & 120.84 & $<0.0001$ \\
\hline $\mathrm{D}^{\wedge} 2$ & 38.69 & 1 & 38.69 & 272.92 & $<0.0001$ \\
\hline Residual & 2.13 & 15 & 0.14 & & \\
\hline Lack of Fit & 1.91 & 10 & 0.19 & 4.52 & 0.0549 \\
\hline Pure Error & 0.21 & 5 & 0.042 & & \\
\hline Cor Total & 183.95 & 29 & & & \\
\hline
\end{tabular}

Estimated coefficients contained in the table is the coefficient of each factor contained in the equation of coded model as follows

$$
\begin{aligned}
& \text { Activity }=7.13+1.47 \mathrm{~A}-0.57 \mathrm{~B}-0.56 \mathrm{C}+0.37 \mathrm{D}+ \\
& 0.28 \mathrm{AB}-0.33 \mathrm{AC}+0.48 \mathrm{AD}+0.62 \mathrm{BC}+0.98 \mathrm{BD}- \\
& 0.06 \mathrm{CD}+0.59 \mathrm{~A}^{2}-0.84 \mathrm{~B}^{2}-0.79 \mathrm{C}^{2}-1.19 \mathrm{D}^{2}
\end{aligned}
$$

Table 2 shows that the interaction effect between $\mathrm{pH}$ and temperature has an insignificant effect because the value of the estimated coefficients is very small when compared with the estimation of coefficients of other factors. Of factors that exist, which have positive effects on cellulase activity of the resulting responses include: The linear effect of rice bran concentration, the linear effect of temperature, and the quadratic effect of substrate concentrations.

Factors that negatively affect the response of cellulase activity include: the linear effect of concentration of coconut water, the linear effect of $\mathrm{pH}$, the quadratic effect of coconut water concentration, the quadratic effect of $\mathrm{pH}$, and the quadratic effect of temperature. 
Table 2. The estimated coefficient of each factor

\begin{tabular}{|c|c|c|c|}
\hline Factor & $\begin{array}{c}\text { Coefficient } \\
\text { Estimate }\end{array}$ & df & $\begin{array}{c}\text { Standard } \\
\text { Error } \\
\end{array}$ \\
\hline Intercept & 7.13 & 1 & 0.150 \\
\hline $\mathrm{A}-\mathrm{C}$ & 1.47 & 1 & 0.077 \\
\hline B-N & -0.57 & 1 & 0.077 \\
\hline C-pH & -0.56 & 1 & 0.077 \\
\hline D-temperature & 0.37 & 1 & 0.077 \\
\hline $\mathrm{AB}$ & 0.28 & 1 & 0.094 \\
\hline $\mathrm{AC}$ & -0.33 & 1 & 0.094 \\
\hline $\mathrm{AD}$ & 0.48 & 1 & 0.094 \\
\hline $\mathrm{BC}$ & 0.62 & 1 & 0.094 \\
\hline $\mathrm{BD}$ & 0.98 & 1 & 0.094 \\
\hline $\mathrm{CD}$ & -0.06 & 1 & 0.094 \\
\hline $\mathrm{A}^{\wedge} 2$ & 0.59 & 1 & 0.072 \\
\hline $\mathrm{B}^{\wedge} 2$ & -0.84 & 1 & 0.072 \\
\hline $\mathrm{C}^{\wedge} 2$ & -0.79 & 1 & 0.072 \\
\hline $\mathrm{D}^{\wedge} 2$ & -1.19 & 1 & 0.072 \\
\hline
\end{tabular}

The two factor interactions which are synergistic interaction include: the interaction between the concentration of rice bran and coconut water, the iinteractions between bran concentration and temperature, the interaction between concentration of coconut water and $\mathrm{pH}$, and the interaction between the concentration of coconut water and temperature. Meanwhile, the interaction of two factors which are antagonistic interactions between each other are: the interaction between concentration and $\mathrm{pH}$ of the bran and the interaction between $\mathrm{pH}$ and temperature.

\section{Conclusion}

RSM optimization model showed optimum values 6.23 for $\mathrm{pH}$ and $40.04{ }^{\circ} \mathrm{C}$, with 14 terms (each with 1 degree of freedom), 4 linear effects, 6 interaction effects and 4 quadratic effects. The optimization by RSM results were slightly different compared to preliminary test, showing the effect of interactions between parameters. The interactions were shown to be: positive effects on cellulase activity of the resulting responses; negative interactions affecting the response of cellulase activity; synergistic interaction; and antagonistic interactions between each other.

The authors are grateful for the financial support provided by PITTA Grant (Publikasi Internasional Terindeks untuk Tugas Akhir) by Universitas Indonesia (contract $\mathrm{Nr}$. 2478/UN2.R3.1/HKP.05.00/2018).

\section{References}

1. M. Gozan, Teknologi Bioetanol Generasi Kedua [in Bahasa], Erlangga Pub. (2016)
2. M. Galbe, and G. Zacchi, Pretreatment of Lignocellulosic Materials for Efficient Bioethanol Production. Adv Biochem Engin/Biotechnol, 108, pp.41-65 (2007).

3. Y.H.P. Zhang, M.E. Himmel, J.R. Mielenz, Outlook for cellulase improvement: screening and selection strategies. Biotechnology advances, 24(5), pp.45281. (2006).

4. S.O. Kotchoni, E. Gachomo, B. Omafuvbe, O.O. Shonukan, Purification and Biochemical Characterization of Carboxymethyl Cellulase (CMCase) from a Catabolite Repression Insensitive Mutant of Bacillus pumilus. International Journal of Agriculture \& Biology, 08(2), pp.286-292 (2006).

5. X.C. Hao, X.B. Yu, and Z.L. Yan, Optimization of the Medium for the Production of Cellulase by the Mutant Trichoderma reesei WX-112 Using Response Surface Methodology. Food Technology Biotechnology, 44(1), pp.89-94 (2006).

6. F. Otajevwo and H.S. Aluyi, Cultural Conditions Necessary For Optimal Cellulase Yield By Cellulolytic Bacterial Organisms As They Relate To Residual Sugars Released In Broth Medium. Nigerian Journal of Microbiology 24(1), pp.21682182 (2010).

7. D. Deka, P. Bhargavi, A. Sharma, D. Goyal, M. Jawed, and A. Goyal, Enhancement of Cellulase Activity from a New Strain of Bacillus subtilis by Medium Optimization and Analysis with Various Cellulosic Substrates. Enzyme research 2011, 151656, p. 8 (2011). doi:10.4061/2011/151656

8. H. Ariffin, N. Abdullah, M.S. Umi Kalsom, Y. Shirai and M.A. Hassan, Production and Characterisation of Cellulase by Bacillus Pumilus Eb3. International Journal of Engineering, 3(1), pp.47-53 (2006).

9. J. Paul and A.K. Varma, Characterization of cellulose and hemicellulose degrading Bacillus sp. from termite infested soil. Current Science, 64(4), pp.262-266 (1993).

10. S. Dahiya, N. Singh and J.S. Rana, Optimization of growth parameters of phytase producing fungus using RSM. Industrial Research, 68 (November), pp.955-959 (2009).

11. M. Gozan, A.M. Biorata, S. Setyahadi, Variation of $\mathrm{C} / \mathrm{N}$ ratio and fermentation time in response surface methodology for cellulase production from Bacillus sp. BPPT CC RK2. International Journal of Pharma and Bio Sciences, 4(4), pp. B1063-B1070 (2013).

12. S.S. Rashid M.Z. Alam, M.I.A. Karim, M.H. Salleh, Optimization of the Nutrient Supplients for Cellulase Production with the Basal Medium Palm Oil Mill Effluent. Media, pp. 809-815 (2009).

13. S.A. Jabasingh, and C.V. Nachiyar, A new combinational statistical approach for cellulase optimization in Aspergillus nidulans. Journal of Science and Technology, 3(8), pp.871-878 (2010).

14. Mathworks, 2011. Response Surface Designs MATLAB \&amp; Simulink Example. Available at: http://www.mathworks.com/help/toolbox/stats/f566 35.html [Accessed January 3, 2012]. 
15. H. Riyanto, S.Y. Martowibowo, Optimization of Organic Rankine Cycle Waste Heat Recovery for Power Generation in a Cement Plant via Response Surface Methodology, Int. J. of Technol. Oct 01, pp 938-945 (2015)

16. T.I. Seo, B.U. Song, K.H. Seo, J.H. Cho, G.S. Yoon, A Study of Optimization of Machining Conditions in Micro End-Milling By Using Response Surface Design, Int. J. of Technol., Jun 01, pp 248-256 (2011)

17. S.Z. Amraini, L.P. Ariyani, S. Setyahadi, H. Hermansyah, S.H. Rahman, D.H. Park, M. Gozan, Production and Characterization of Cellulase from E. coli EgRK2 Recombinant based, Biotechnology and Bioprocess Engineering 22: 287-295 (2017).

18. L.J. Yin, P.S. Huang, and H.H. Lin, Isolation of cellulase-producing bacteria and characterization of the cellulase from the isolated bacterium Cellulomonas sp. YJ5. Journal of agricultural and food chemistry, 58(17), pp.9833-7 (2010).

19. G.L. Miller, Use of Dinitrosalicylic Acid Reagent for Determination of Reducing Sugar. Analytical Chemistry, 31(3), pp.426-428 (1959).

20. O.H. Lowry, R.J. Randall and A. Lewis, Protein Measurement with The Folin Phenol Reagent. Journal of Biological Chemistry (1951)

21. L.C.A. da Silva, T.L. Honorato, R.S. Cavalcante, T.T. Franco, and S. Rodrigues, Effect of $\mathrm{pH}$ and Temperature on Enzyme Activity of Chitosanase Produced Under Solid Stated Fermentation by Trichoderma spp. Indian $J$ Microbiol. 52(1): 60-65 (2012)

22. G. Immanuel, R. Dhanusha, P. Prema, A. Palavesam, Effect of different growth parameters on endoglucanase enzyme activity by bacteria isolated from coir retting effluents of estuarine environment. International Journal Environmental Science Technology 2(1), pp.25-34 (2006). 